\title{
Distribution and damage characteristics of Analeptes trifasciata Fabricius 1775 (Coleoptera: cerambycidae) on cashew (Anacardium occidentale linnaeus 1753) in Nigeria
}

\author{
Asogwa, E.U. ${ }^{1}$; T.C.N. Ndubuaku ${ }^{1}$ and A.T. Hassan ${ }^{2}$ \\ ${ }^{1}$ Entomology Section, Cocoa Research Institute of Nigeria, Ibadan, Nigeria \\ ${ }^{2}$ Zoology Department, University of Ibadan, Ibadan, Nigeria \\ Corresponding Author: ucheasogwa1@yahoo.com
}

\begin{abstract}
The infestation of cashew, Anacardium occidentale by Analeptes trifasciata, is on the increase and poses serious threat to cashew cultivation in Nigeria. There is dearth of base-line information on $A$. trifasciata in Nigeria. This study was conducted to provide more information on the distribution and damage characteristics of the pest in Nigeria. A survey of infestation by A. trifasciata was carried out in the Federal Capital Territory and 25 States of Nigeria that grow cashew in order to ascertain the geographical spread of the pest. A random sampling of 1000 cashew trees was carried out in each State. The monthly distribution and damage assessments of the pest were carried out at the Cocoa Research Institute of Nigeria (CRIN) Ibadan cashew research plots (N7/3, SW3/2, SS6) and its Ochaja Sub-station plots (NW1, NW7, SE5A) by sampling 100 randomly selected cashew trees at each plot. Data generated were analyzed with Student's T-test. Analeptes trifasciata was found in South-East, South-West, South South and North-Central geopolitical zones of Nigeria. Pronounced infestation levels of $42.7 \%$ to $82.6 \%$ were recorded, the highest in Kogi State (82.6\%) followed by Oyo (79.3\%), Abia (62.4\%), Imo (61.3\%), Osun (61\%) and Anambra (59.3\%) States. The devastating effects of the insect were not noticed in Akwa-lbom, Bayelsa and Rivers States. Peak infestation (117 - 130 adult Analeptes) per plot was recorded in September to December, and least (7 Analeptes) in June. Analeptes trifasciata population was more abundant in Oyo State $(554.3 \pm 41.3)$ than Kogi State (360.7 \pm 42.4). However a higher number of girdled-branches, $535.8 \pm 27.6$ /hectare was recorded for Kogi State when compared with $323.7 \pm 18.4$ for Oyo State. The wide spread of $A$. trifasciata infestation in most cashew growing states has made it an economic pest. The girdling of cashew by the adult insect in highly infested plantations leads to significant damages. Control measures in Nigeria should target the peak periods of infestation to reduce losses in cashew production.
\end{abstract}

Keywords: Analeptes trifasciata, Anacardium occidentale, Tree infestation, Girdling.

\section{INTRODUCTION}

Cashew, Anacardium occidentale belongs to the family Anacardiaceae. Cashew is indigenous to South America and was introduced into Nigeria by Portuguese explorers in the $15^{\text {th }}$ and $16^{\text {th }}$ centuries (Ohler, 1967; 1979; Togun, 1977). In Nigeria, commercial plantations of cashew were developed simultaneously by the Eastern and Western Nigerian Development Corporations at Oghe and Iwo/Eruwa respectively (Togun, 1977). From these locations, it's planting spread to other parts of Nigeria (Olunloyo and Igboekwe, 1985).

The cashew nut contains $47 \%$ fat, $21 \%$ protein, $22 \%$ carbohydrate, and vitamins, especially thiamine
(Ohler, 1966; 1979; Nandi, 1998). The kernels are used for making chocolates and edible oil of excellent quality (Ojeh and Falowo, 1983; Ojeh, 1985). The cashew nut shell liquid (CNSL), is used widely in brake linings of motor vehicles, paints, varnishes and laminated products (Murthy and Sivasambari, 1985). It is also used as a plywood adhesive (Akaranta et al., 1996). CNSL and other extracts from the shell are larvicidal (Carrara et al., 1984; Evans and Raj, 1988) molluscicidal (Casadei et al., 1984; Kubo et al., 1986) and antifungal and antibacterial (Echendu, 1991; Weerasena et al., 1993). It is also in itself very useful for insecticidal, fungicidal, anti-termite and medicinal applications, and as an additive, in many plastic 
formulations (Lepage and Delelis, 1980; Gowri and Saxena, 1997; Lubi and Thachil, 2000).

Cashew, like most tree crops hosts a wide range of pests and diseases. Insect pests infest its various parts including roots, stem, branches, flowers and the pseudo-apples (Eguagie, 1972; 1973; 1974; Olunloyo, 1989; Asogwa et al., 2009). In Nigeria, little or no importance was accorded to the "longicorn" beetle Analeptes trifasciata Fabricius (Coleoptera: Cerambycidae) in the past, but recently the rise in the infestation of the pest is posing serious threat to cashew cultivation. Presently, there is dearth of indepth base-line information on all aspects of the pest. This study was undertaken to provide information on the distribution and damage characteristics of $A$. trifasciata.

\section{MATERIALS AND METHODS}

Survey of the spread of $A$. trifasciata: A survey of the spread of $A$. trifasciata was carried out in cashew plantations within the Federal Capital Territory and twenty five (25) States (Abia, Akwa-lbom, Anambra, Bayelsa, Benue, Cross-River, Delta, Ebonyi, Edo, Ekiti, Enugu, Imo, Kaduna, Kogi, Kwara, Lagos, Nasarawa, Niger, Ogun, Ondo, Osun, Oyo, Plateau, Rivers and Taraba States) of Nigeria in 2006. These States are all known to have natural environments that support the growth of cashew according to earlier Cashew Production Survey Reports in Nigeria (Ayodele et al., 2001; Topper et al., 2001; ADAN, 2002; Ezeagu, 2002; FAO, 2007; Hammed et al., 2007; Aliyu and Hammed, 2008; Asogwa et al., 2008). From each State a random sample of 1000 cashew plants were selected from Government or Institutional farms as well as private farms and homesteads for assessment. The presence of $A$. trifasciata or their damage characteristics on the cashew trees (girdled points on trees, girdled stems still hanging on the trees or fallen to the ground) was used as the basis to establish their relative distribution in the different States.

Monthly occurrence of $A$. trifasciata infestation: Following the initial survey of the distribution of $A$. trifasciata in 25 States, 2 States (Oyo and Kogi) with high infestation rates were chosen for the study of monthly occurrence of infestation. Three cashew plots (N7/3, SW3/2 and SS6), each serving as a replicate with 100 randomly selected plants were mapped out at the Cocoa Research Institute of Nigeria headquarters (Oyo State) to determine the monthly infestation of $A$. trifasciata in 2007. The same was replicated at Ochaja CRIN substation, Kogi State in cashew plots NW1, NW7 and SE5A. Their infestation rates characterized by girdled points on trees, girdled stems still hanging on the trees or fallen to the ground were recorded monthly for each plot.

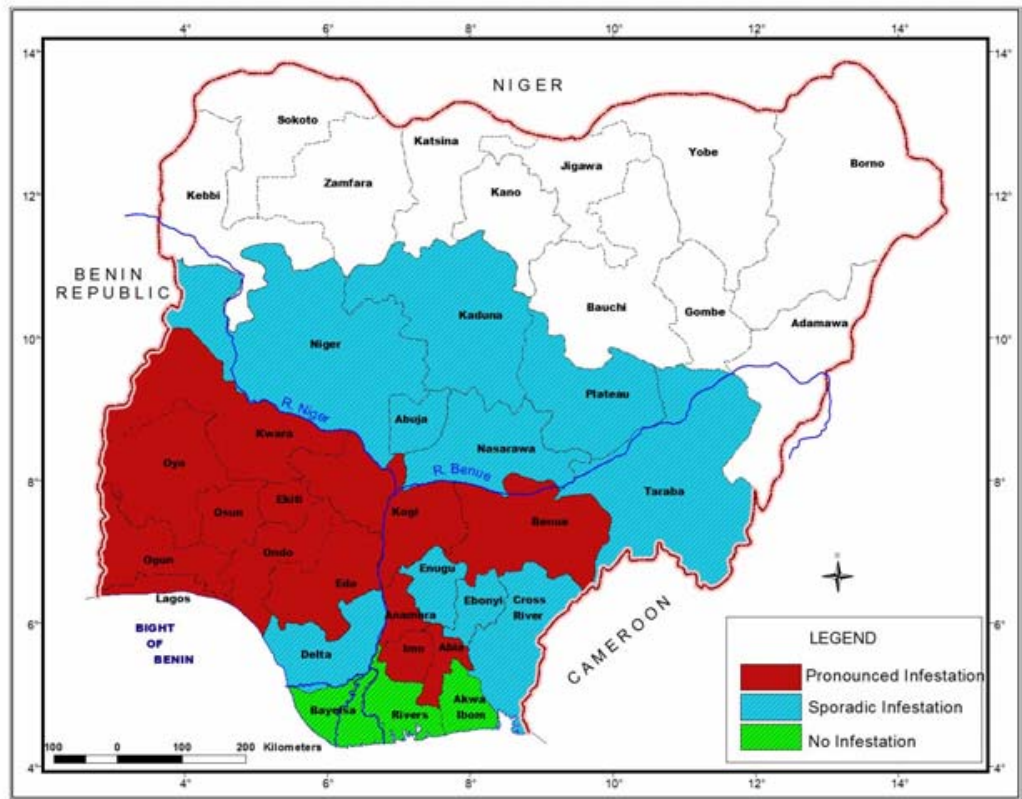

Fig 1: Map of Nigeria showing the spread of $A$. trifasciata 


\section{AGRICULTURE AND BIOLOGY JOURNAL OF NORTH AMERICA}

ISSN Print: 2151-7517, ISSN Online: 2151-7525, doi:10.5251/abjna.2011.2.3.421.431

(C) 2011, ScienceHuß, http://www.scihub.org/ABJNA

Population count of $A$. trifasciata: A population count of the number of $A$. trifasciata found on the cashew trees was taken monthly on 3 cashew plots (N7/3, SW3/2 and SS6) at CRIN headquarters and 3 plots (NW1, NW7, and SE5A) at Ochaja CRIN substation to determine the relative abundance of $A$. trifasciata in 2007. The insects were collected with the aid of a long pole, which was used to gently pull them down from the cashew treetop to the ground. They were picked up and placed inside an insect collection box, while those within hand height were picked up directly from the cashew stems. Sexes of the insects were observed and recorded.

Damage characteristics of $\boldsymbol{A}$. trifasciata: The activities of $A$. trifasciata were randomly observed in its natural habitat on all the selected cashew plots at CRIN headquarters and Ochaja substation for ten days. The $A$. trifasciata found on the trees were monitored daily at random time intervals between $7 \mathrm{am}$ to $6 \mathrm{pm}$ to ascertain the following: their mode of destruction, parts of cashew plant destroyed and the type of damage signs left behind by the insects. Photographs of the insect's activities were taken with zoom lens digital camera (Canon SD850 IS) for photo documentations.

\section{RESULTS}

Survey of the spread of $A$. trifasciata: The result of the survey (Table 1) showed outstanding levels of devastation of the cashew farms by $A$. trifasciata in most States surveyed. The highest infestation rate of $82.6 \%$ was recorded for Kogi State, which was closely followed by Oyo (79.3\%), Abia (62.4\%), Imo (61.3\%), Osun (61\%) and Anambra (59.3\%). The devastating effects of the insect were not noticed in Akwa-lbom, Bayelsa and Rivers States. A very low rate of infestation was recorded for Plateau (5.6\%), FCT (8\%), Niger (12.5\%), Taraba (12.7\%), Kaduna $(13 \%)$ and Enugu (13.7\%). Figure 1 is a map of Nigeria showing the geographical spread of $A$. trifasciata. There was a pronounced presence (infestation) of $A$. trifasciata in Oyo, Kwara, Osun, Ekiti, Ogun, Ondo, Edo, Kogi, Lagos, Benue, Anambra, Imo and Abia states (red parchment). The beetles were not noticed in Akwa-lbom, Bayelsa and Rivers States (green parchment), however, there was a sporadic infestation in Niger, Kaduna, FCT, Nassarawa, Plateau, Taraba, Enugu, Ebonyi, CrossRiver and Delta states (blue parchment). The amber colour parchments on the map indicate areas with pronounced presence of $A$. trifasciata, the yellow parchment shows states with sporadic occurrence, while the light yellow parchment indicates states where no infestation of $A$. trifasciata was noticed in all the cashew plantations/homestead assessed.

Monthly occurrence of $A$. trifasciata infestation: A monthly survey of randomly selected cashew plants at CRIN and Ochaja cashew plots showed declining trend of the pest infestation from January to March, with no occurrence in April to August An increased infestation of the pest followed from September to December (Fig 2). The number of $A$. trifasciata girdled branches collected at Ochaja plots (535.78 \pm 27.6) differed significantly $(P<0.05)$ from that of Ibadan plots $(323.72 \pm 18.4)$ (Table 2). All the cashew trees at Ochaja experimental plots (100\%) had some degree of infestation on them by the pest within the experimental period; however, it did not differ significantly from the infestation rate at Ibadan plots (84.3\%).

Population count of $A$. trifasciata: A monthly survey of randomly selected cashew plants at CRIN and Ochaja cashew plots showed declining trend of the pest population from January to March, with little occurrence in June. An increased population of the pest followed from September to December (Fig 3). The population of the pest was relatively higher at CRIN plots $(554.33 \pm 41.3)$ compared to Ochaja plots (360.67 \pm 42.4$)$. The mean monthly population count of $A$. trifasciata at Ibadan (276.7 males and 277.6 females) and Ochaja (179.5 males and 181.1 females) cashew plots showed no significant difference between the number of males and females collected (Table 3 ). The insects were always found in pairs in all the plots, but when disturbed, they hide or fly away from the source of disturbance.

Damage characteristics of $A$. trifasciata: Analeptes trifasciata is a low-density pest which girdles cashew branches resulting in their death from the point of girdling (Plate 1). Some of the girdled stems snap and hang on cashew tree tops, while others fall to the ground (Plates 2 and 3 ). Stumps of affected branches usually regenerate and produce many side shoots, giving an untidy appearance (Plate 4). In some cases, the girdled cashew branch recovers by producing a lot of gum exudates around the girdled portion, followed by an outgrowth to heal the wound (Plate 5). They feed by scraping the bark of the cashew stems (Plate 6) and usually mate and lay their eggs below the bark above the girdled portion of the cashew branch that will hang or fall to the ground (Plate 7). The beetles do not feed on or directly damage other cashew parts (leaves, flowers, fruits and nuts). 


\section{AGRICULTURE AND BIOLOGY JOURNAL OF NORTH AMERICA}

ISSN Print: 2151-7517, ISSN Online: 2151-7525, doi:10.5251/abjna.2011.2.3.421.431

(C) 2011, ScienceHu $\beta$, http://www.scihub.org/ABJNA

Table 1: $\quad$ Geographical spread of Analeptes trifasciata in Nigeria

\begin{tabular}{|c|c|c|c|c|}
\hline \multicolumn{2}{|c|}{ States. } & No of trees & \multirow{2}{*}{$\begin{array}{l}\text { Number of } \\
\text { trees infested. }\end{array}$} & \multirow[t]{2}{*}{$\%$ Infestation } \\
\hline & & sampled. & & \\
\hline 1. & Abia & 1000 & 624 & 62.4 \\
\hline 2. & Akwa-Ibom & 1000 & 0 & 0 \\
\hline 3. & Anambra & 1000 & 593 & 59.3 \\
\hline 4. & Bayelsa & 1000 & 0 & 0 \\
\hline 5. & Benue & 1000 & 427 & 42.7 \\
\hline 6. & Cross-River & 1000 & 233 & 23.3 \\
\hline 7. & Delta & 1000 & 325 & 32.5 \\
\hline 8. & Ebonyi & 1000 & 215 & 21.5 \\
\hline 9. & Edo & 1000 & 505 & 50.5 \\
\hline 10. & Ekiti & 1000 & 578 & 57.8 \\
\hline 11. & Enugu & 1000 & 137 & 13.7 \\
\hline 12. & F.C.T & 1000 & 80 & 8 \\
\hline 13. & Imo & 1000 & 613 & 61.3 \\
\hline 14. & Kaduna & 1000 & 130 & 13 \\
\hline 15. & Kogi & 1000 & 826 & 82.6 \\
\hline 16. & Kwara & 1000 & 437 & 43.7 \\
\hline 17. & Lagos & 1000 & 479 & 47.9 \\
\hline 18. & Nasarawa & 1000 & 251 & 25.1 \\
\hline 19. & Niger & 1000 & 125 & 12.5 \\
\hline 20. & Ogun & 1000 & 538 & 53.8 \\
\hline 21. & Ondo & 1000 & 512 & 51.2 \\
\hline 22. & Osun & 1000 & 610 & 61 \\
\hline 23. & Oyo & 1000 & 793 & 79.3 \\
\hline 24. & Plateau & 1000 & 56 & 5.6 \\
\hline 25. & Rivers & 1000 & 0 & 0 \\
\hline 26. & Taraba & 1000 & 127 & 12.7 \\
\hline
\end{tabular}

Table 2: The incidence of $A$. trifasciata infestation on cashew plots

\begin{tabular}{llcc}
\hline Locations $^{*}$ & Total no of girdled & Mean no of infested trees & \%Infestation branches \\
\hline Ibadan & $323.72 \pm 18.4$ & 84.3 & $84.3 \%$ \\
$\begin{array}{l}\text { Ochaja } \\
t 0.03(p=0.05)\end{array}$ & $\begin{array}{l}535.78 \pm 27.6 \\
\text { ** }\end{array}$ & $\begin{array}{l}100 \\
\text { ns }\end{array}$ & $100 \%$ \\
\hline
\end{tabular}

*Each location value represents a mean of three replicate plots of 100 cashew stands each.

** - Significant difference

ns - No significant difference

Table 3: Number of $A$. trifasciata collected from the various cashew plots

\begin{tabular}{lllll}
\hline Locations $^{*}$ & Total no of insects & No of males & No of females \\
\hline Ibadan & $554.33 \pm 41.3$ & 276.7 & 277.6 & $n s$ \\
Ochaja & $360.67 \pm 42.4$ & 179.5 & 181.1 & ns \\
$t 0.03(p=0.05)$ & $* *$ & $* *$ & \\
\end{tabular}

*Each location value represents a mean of three replicate plots of 100 cashew stands each.

** - Significant difference

ns - No significant difference 


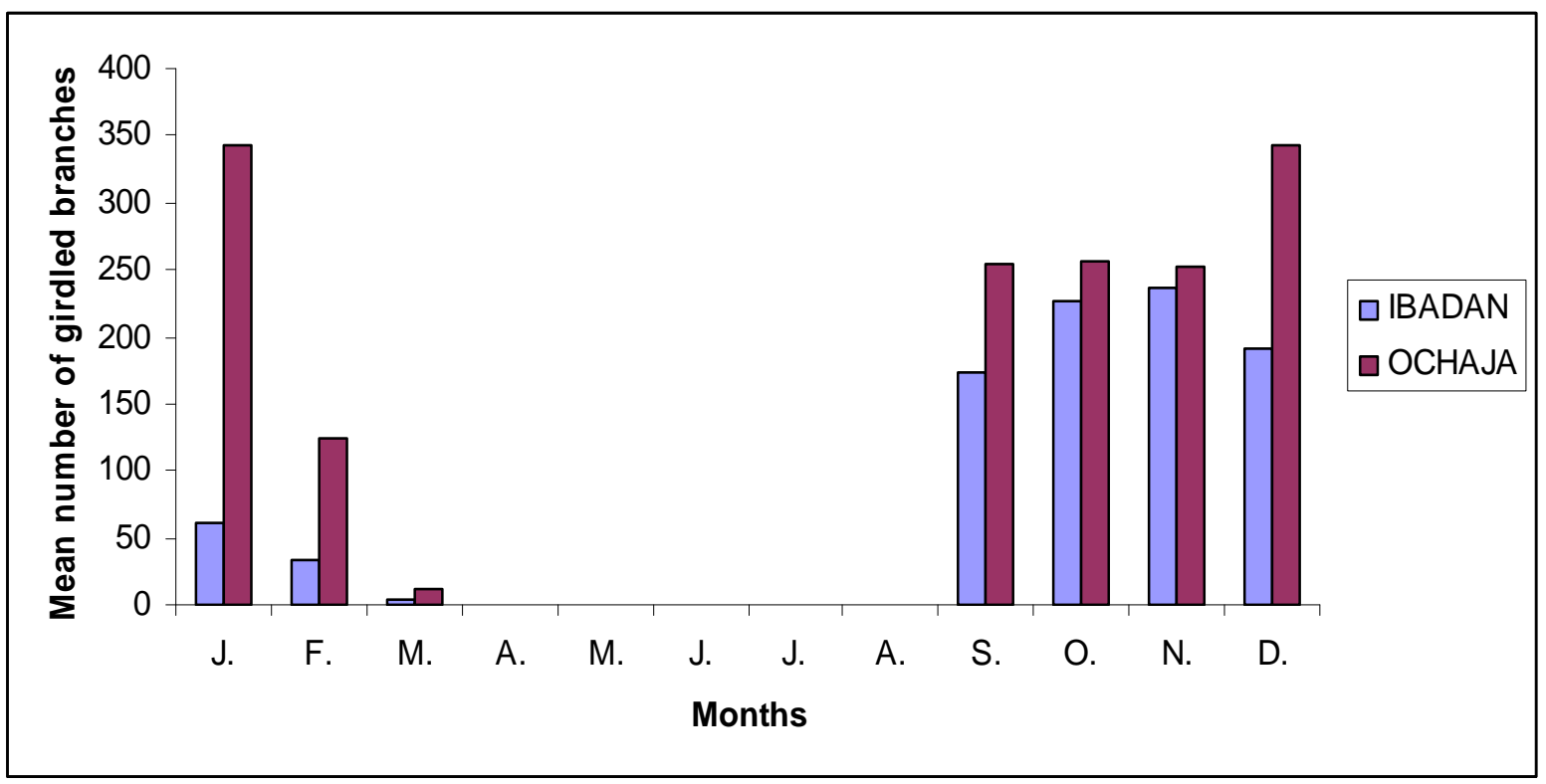

Fig 2: Number of girdled branches collected from cashew plots at Ibadan and Ochaja

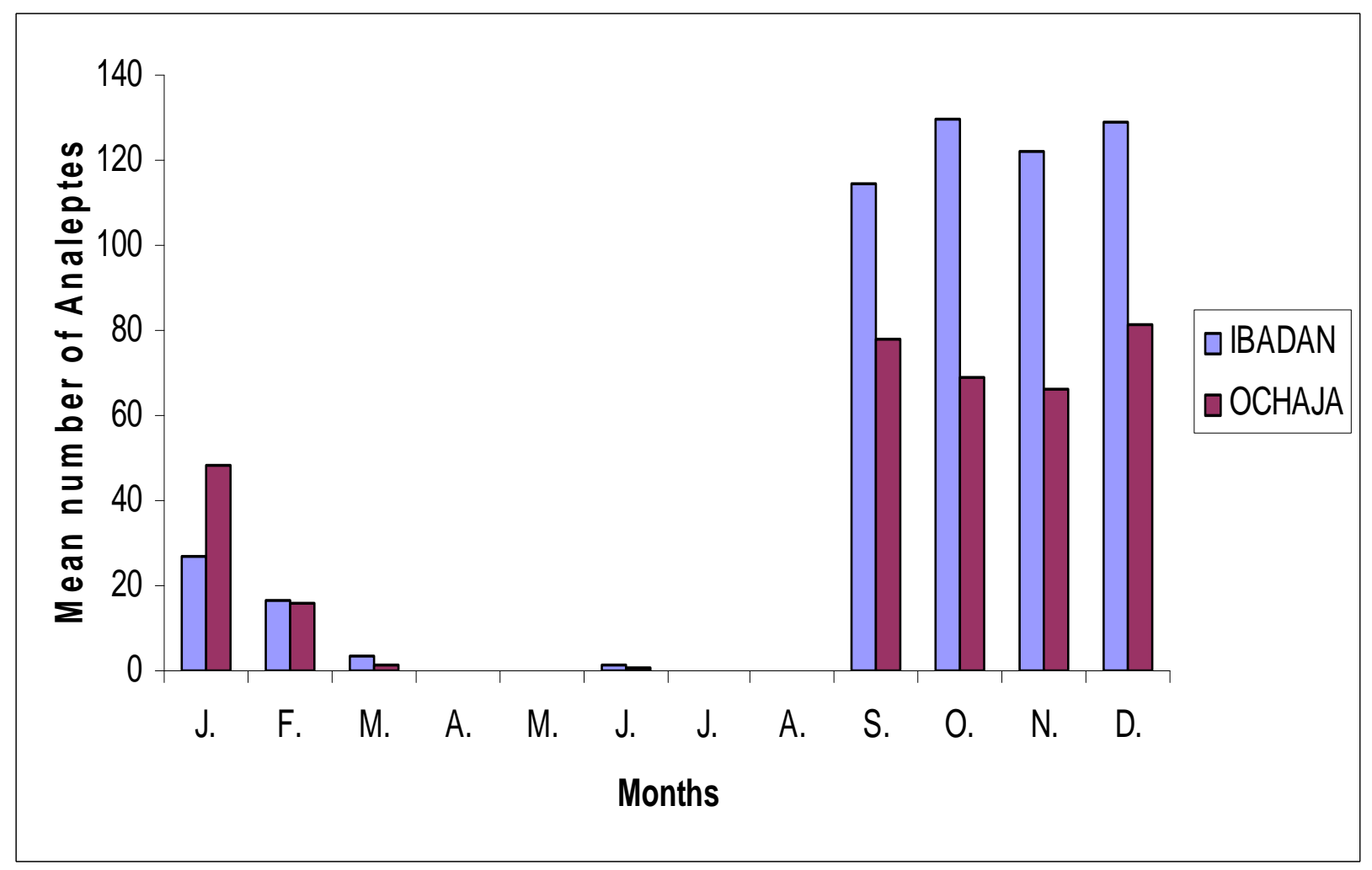

Fig 3: Monthly distribution of $A$. trifasciata on cashew plots at Ibadan and Ochaja 
Agric. Biol. J. N. Am., 2011, 2(3): 421-431

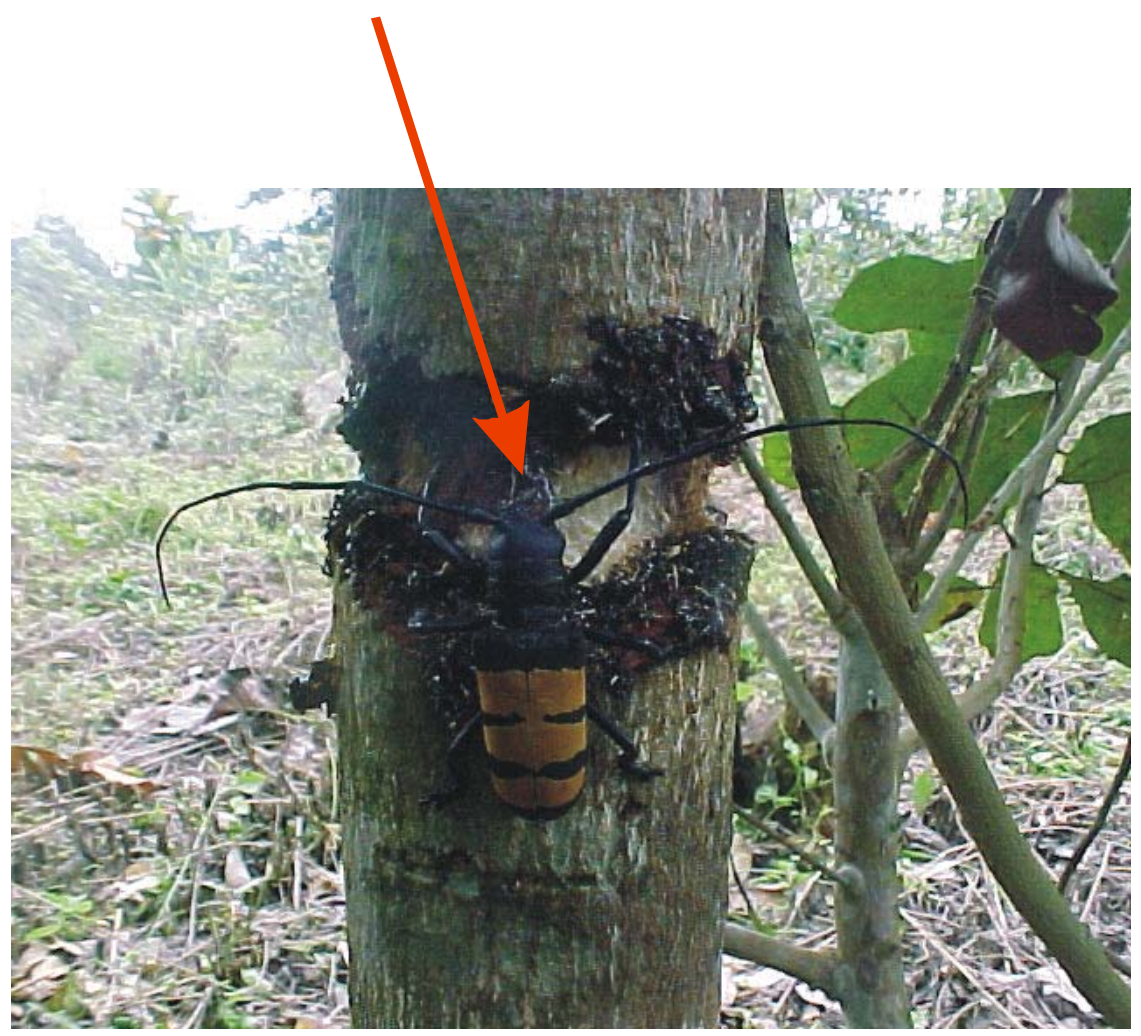

Plate 1: The cashew stem girdler (Analeptes trifasciata) and its amage pattern

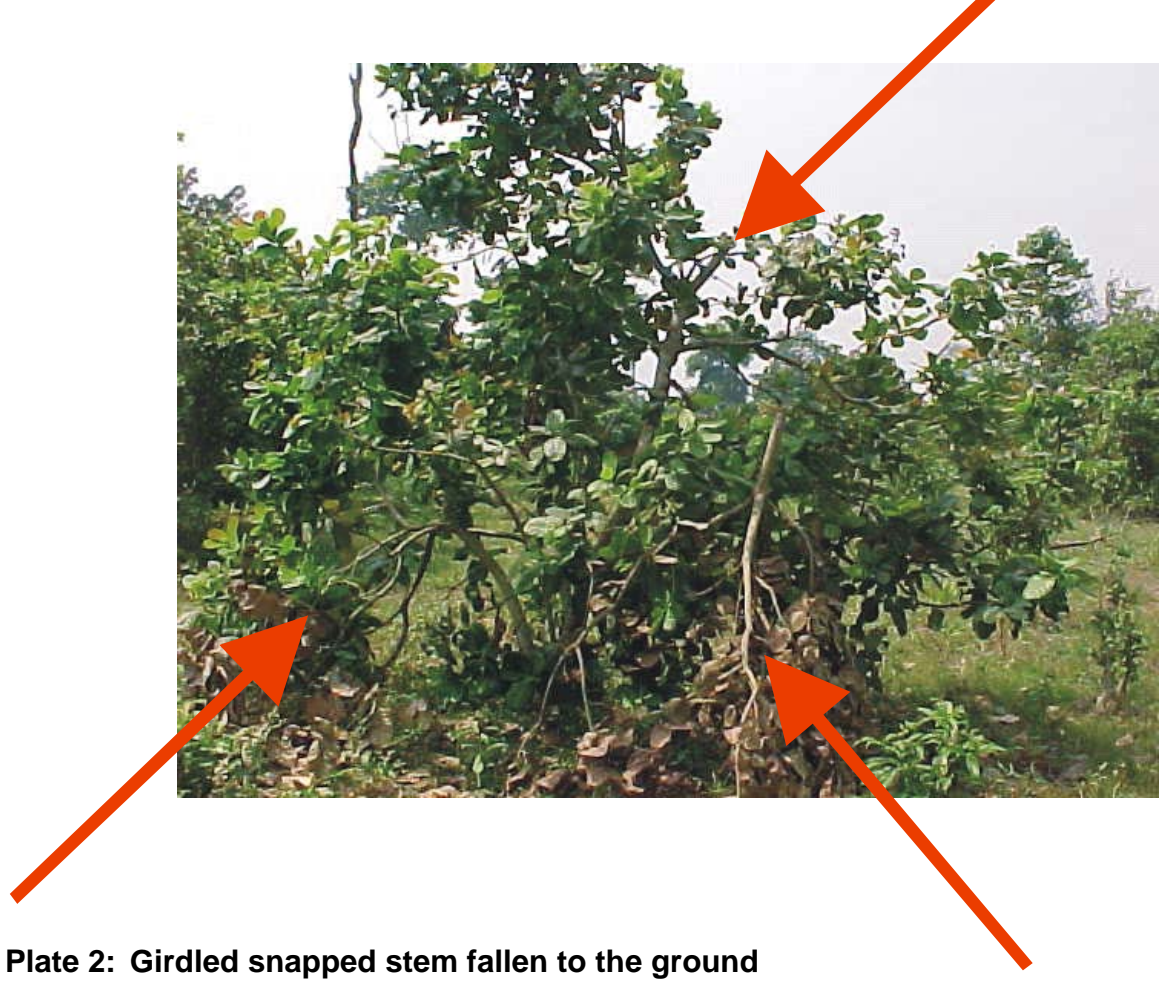


Agric. Biol. J. N. Am., 2011, 2(3): 421-431

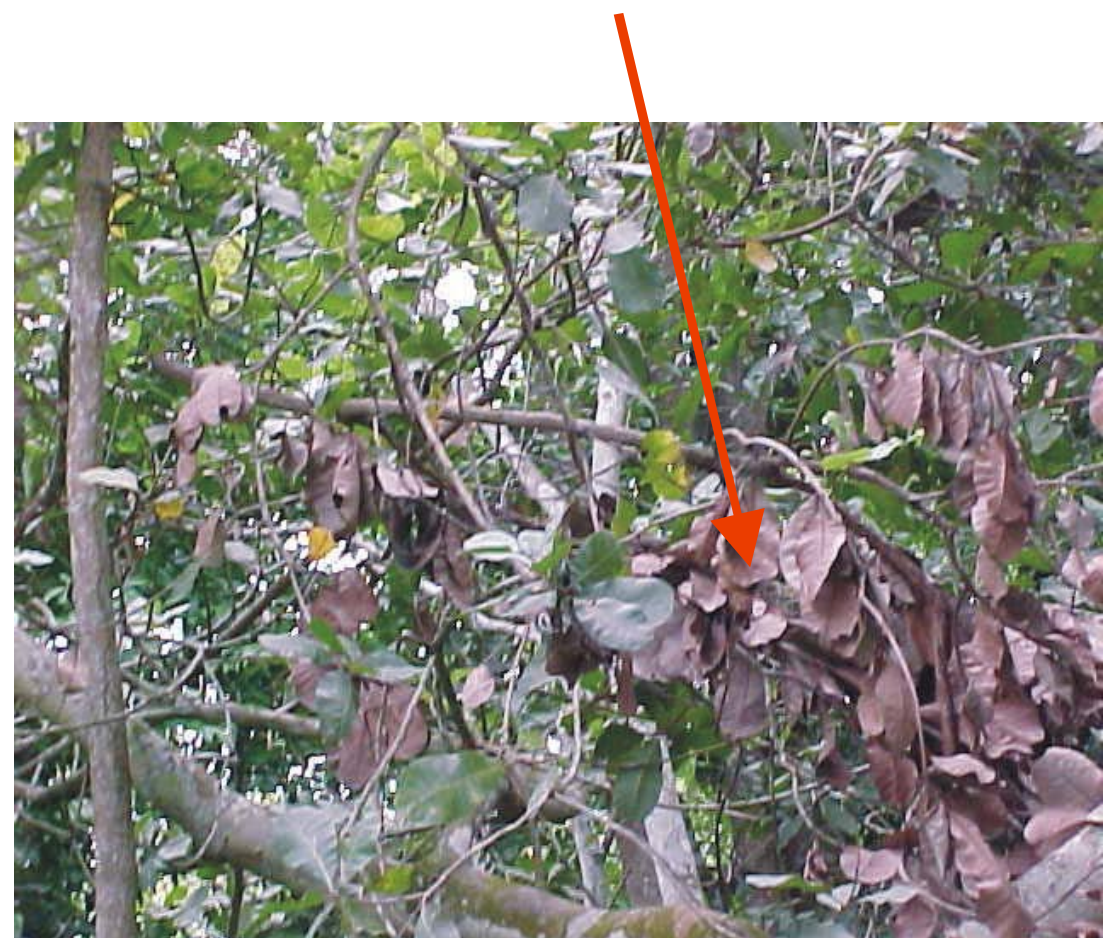

Plate 3: Girdled snapped stem still hanging on tree top.

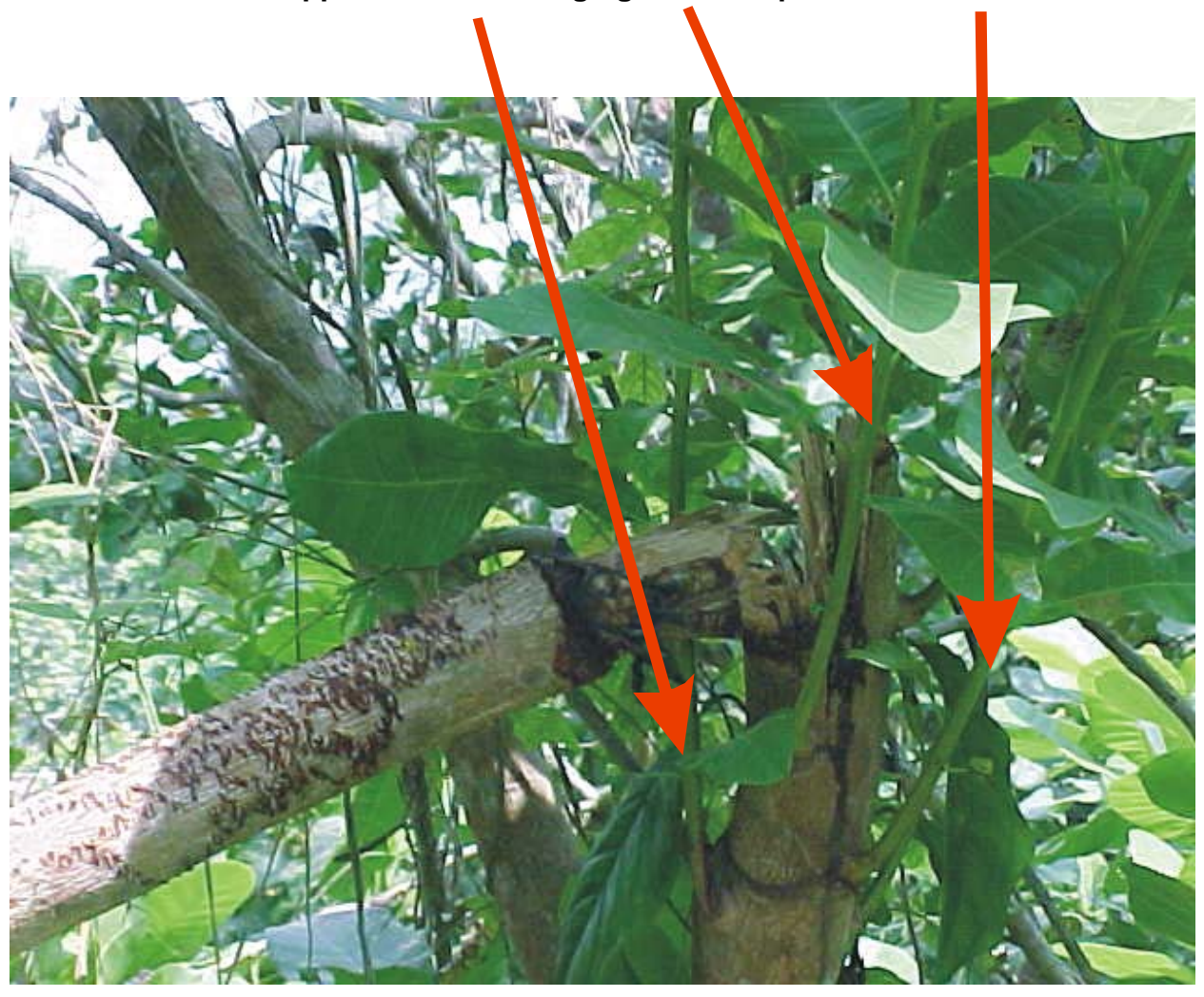

Plate 4: Regenerated stump of girdled cashew branch by Analeptes trifasciata with many side shoots 
Agric. Biol. J. N. Am., 2011, 2(3): 421-431

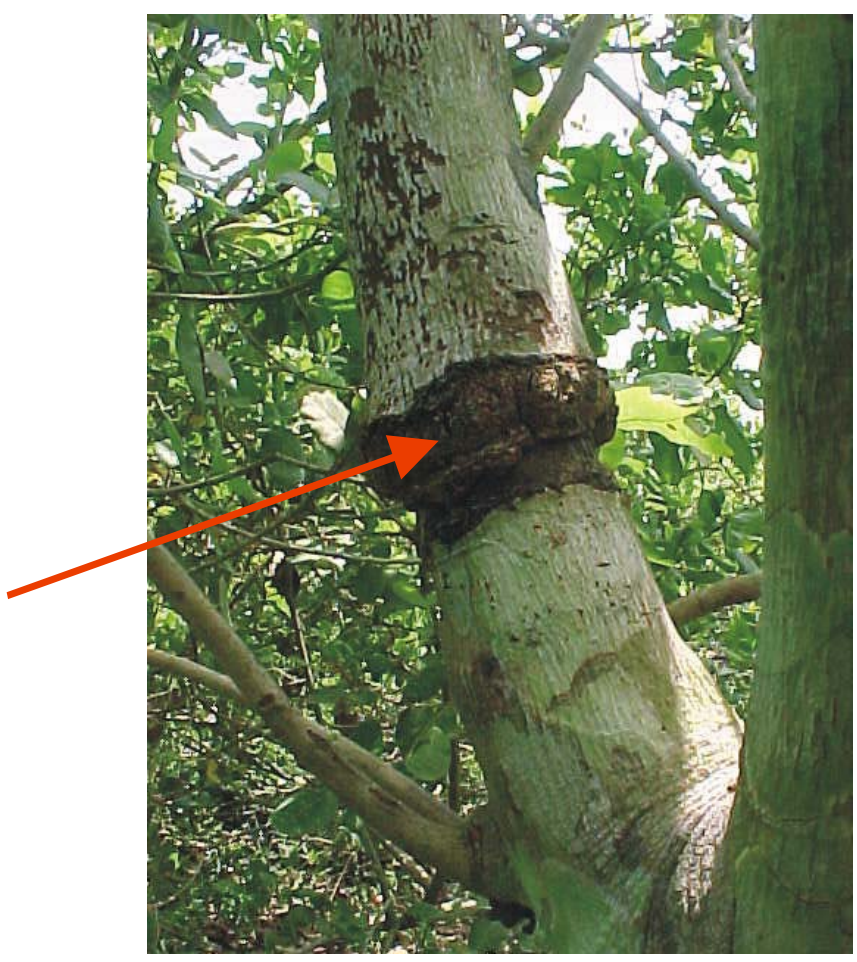

Plate 5: A girdled cashew branch that recovered from girdling effects of $A$. trifasciata

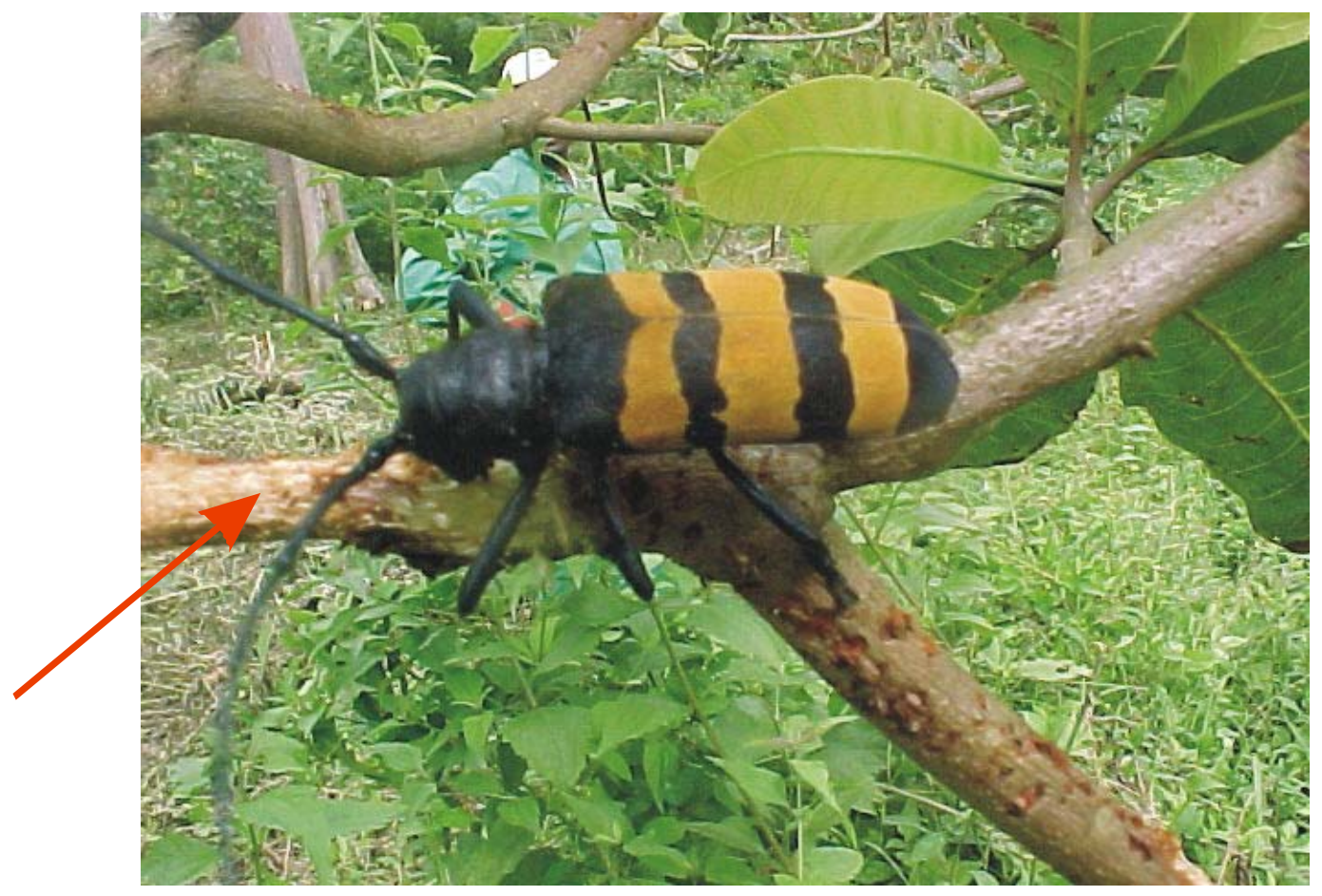

Plate 6: Scraping of bark of cashew branch, characteristics feeding sign of $A$. trifasciata 
Agric. Biol. J. N. Am., 2011, 2(3): 421-431

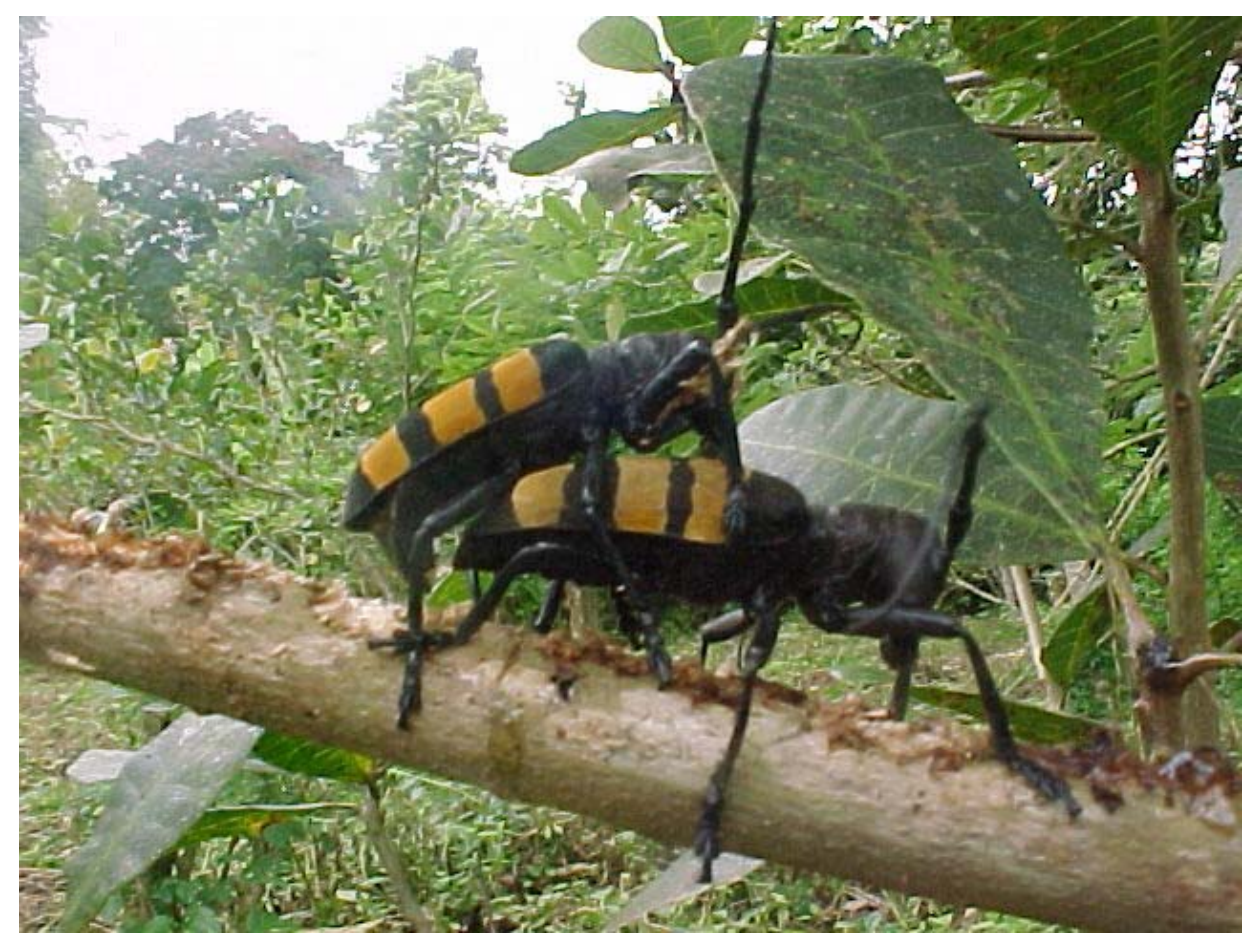

Plate 7: Mating of $A$. trifasciata after feeding and girdling a cashew branch

\section{DISCUSSION}

Results from this study showed that the cashew stem girdler, A. trifasciata (Coleoptera: Cerambycidae) is a major pest of cashew in Nigeria. This is in line with earlier reports by Omole, 1977; Igboekwe, 1982; $1983 ; 1984 ; 1985)$. Earlier report of the survey of the incidence of $A$. trifasciata by Igboekwe, (1983), showed that it is prevalent in cashew plots in Oyo, Anambra and Benue States. The report of this study therefore, is an extension of the information on the relative abundance of $A$. trifasciata in additional 22 States of Nigeria. The relative distribution of the beetle in 22 out of the 25 States surveyed corroborates earlier reports by Topper (2002), which stated that damage by the insect was mainly seen in Nigeria, even though it has been reported, as being a problem in all the five African countries surveyed. Analeptes trifasciata was also found on cashew in Afram plains, $\mathrm{Ga}$ districts and some parts of central region of Ghana (Dwomoh et al., 2008).

The relative high population of the beetles noted at Ibadan plots could be attributed to differences in environmental factors (vegetation, rainfall, temperature and relative humidity) between Ochaja and Ibadan. Ibadan is a typical marginal rainforest region that supports a wide range of alternate host trees of $A$. trifasciata. Most of these host trees were not found at Ochaja.

The high number of girdled branches in January at Ochaja (Fig 2) was a fallout from the previous year's infestation of the plots. Cultural control programme for the pest was not in place at the plots unlike the Ibadan plots prior to the commencement of the experiment. The monthly occurrence of the beetle observed in both locations differed from earlier reports by Adeyemo, (1988), which recorded June/July as the peak period of the beetle in the cashew plots. Also Igboekwe, (1983), reported slight peak population of the beetle in July followed by a peak population in November. The beetles were found on mature cashew trees from January to April in Bole, Damongo, Tabiasi and Drobo districts of Ghana (Dwomoh et al., 2008). However, it is worthy to note that with good farm sanitation put in place in the course of this study, the relatively high population of the beetles reported earlier between May to August each year was drastically reduced. All the hanging girdled branches and those fallen to the ground were removed from the cashew plots on monthly basis and burnt, which tremendously reduced the rate of reinfestation. The snapped fallen and hanging branches are known to be the breeding sites for the pest, so removal and burning them 
outside the plantation would destroy the eggs, larvae and pupae, thereby reducing future infestation by the adult insect.

Girdled cashew branches usually snap and either fall to the ground or remain hanging on the tree top. This results in a serious economic loss to the farmers, as all the flowers, pseudo apples, nuts and ripe apples on such branches are lost. The stumps of cut or snapped branches generally regenerate and produce many side shoots giving an untidy appearance. The regenerated flushy shoots attract foliar pests, which damage the apical portion and reduce photosynthetic activities of the tree. Such side shoots if not pruned immediately result in overcrowded stems with etiolated growth, which produce little or no fruits on them.

The large numbers of girdled stems hanging on treetops and beyond hand reach after snapping make it very difficult to eradicate this pest from cashew plantations. Their eggs develop unhindered on such stems hanging on treetop until the metamorphosis is complete shortly or after the branches decay and fall to the ground on their own resulting in reinfestation of the plots by another generation of the insect. The farmers find it difficult to afford the extra costs required to remove these hanging branches from the treetops. The girdling and snapping of the cashew branches usually occur during the flowering period of cashew. The farmers at this period do not usually bother to remove the hanging branches to avoid high flower shedding that could occur in the process of pulling down the braches.

\section{CONCLUSION}

The control measures of $A$. trifasciata in Nigeria should target the peak periods of infestation to reduce losses in cashew production.

\section{ACKNOWLEDGEMENT}

We wish to thank the entire Staff and Management of the Cocoa Research Institute of Nigeria, Ibadan for their support. We also appreciate all the Heads of the various CRIN Sub-stations and the members of staff of the State's Agricultural Development Programs (ADPs) who assisted in the survey.

\section{REFERENCES}

ADAN (2002). Final report Agricultural Development Assistance to Nigeria. RAISEChemonics International Inc. $113320^{\text {th }}$ Street NW Washington DC, 20036.

Adeyemo, Y.A (1988). Population studies on cashew insect pests.CRIN Annual Report. pp. 48-49.
Akaranta, O.; W. Donbebe and T.O. Odozi (1996). Plywood adhesives based on red- onion-skin extract modified with cashew nut-shell liquid. Bioresource Technol. 56: 279-280.

Aliyu, O. M. and L.A. Hammed. (2008). Nigerian cashew economy: A review of nut production sector. Paper presented at the International Academy of African Business and Development (IAABD) Conference. University of Florida,Gainesville, USA. May 20-24, 2008.

Asogwa E.U.; L.A. Hammed and T.C.N. Ndubuaku (2008). Integrated production and protection practices of cashew, Anacardium occidentale in Nigeria. African J.Biotech. Vol. 7 (25): 4868-4873.

Asogwa, E.U.; J.C. Anikwe; T.C.N. Ndubuaku and F.A. Okelana (2009) Distribution and damage characteristics of an emerging insect pest of cashew, Plocaederus ferrugineus L. (Coleoptera: Cerambycidae) in Nigeria: A preliminary report. African Journal of Biotechnology. Vol. 8(1): 053 - 058.

Ayodele, E. A.; P.O. Adebola; O.M. Aliyu and O. Olubamiwa (2001). Research aspect of the cashew industry in Nigeria. Paper presented at $1^{\text {st }}$ Annual Conference of National Cashew Association of Nigeria (CAN), October $2001.19 \mathrm{pp}$.

Carrara, G.; G.C. Munoz and L. Damho (1984). Larvicidal effect of cashew nut husk bagasse: Its possible use in malariology in the antivector control programmes. Revista Medica de Mocambique. 2: 78-82.

Casadei, E.; S. Bruheim and T. Latis (1984). Active substances in cashew nutshell with molluscicidal activity: Possible use in Schistosomiasis control programmes. Revista Medica de Mocambique. 2: 3539 .

Dwomoh, E.A.; J.B. Ackonor and J.V.K. Afun (2008) Survey of insect species associated with cashew (Anacardium occidentale Linn) and their distribution in Ghana. African Journal of Agricultural Research. Vol 3(3): 205-214.

Echendu, T.N.C. (1991). Ginger, Cashew and Neem as surface protectants of cowpeas against infestation and damage by Callosobruchus maculatus. Tropical Science. 31: 209-211.

Eguagie, W.E. (1972) Insects associated with cashew Anacardium occidentale in Nigeria. Ann, Rep. CRIN, Ibadan, Nigeria. Pp.134-137.

Eguagie, W.E. (1973) Insect associated with cashew, A. occidentale in Nigeria. CRIN Ann. Rep. Pp. 270-273.

Eguagie, W.E. (1974) Insects associated with cashew, A. occidentale in Western Nigeria. CRIN. Ann. Rep. Pp. 128-130. 
Evans, D.A. and R.K. Raj (1988). Extracts of Indian plants as mosquito larvicides. Indian J. Med. Res. 88: 38-41.

Ezeagu, W. (2002). Nigeria assessment of the situation and development prospects of the cashew nut sector. Draft Report No. INT/W3/69. International Trade Centre UNCTAD/INTO (ITC), Abuja, Nigeria. Pp. 1-36.

FAO (2007) Food and Agriculture Organization, Statistics Division. Available

online@http://faostat.fao.org/site/336/DesktopDefault.a spx?PagelD=336

Gowri, V.S. and M. Saxena (1997). Protection of bamboo surface by CNSL based coatings. India J. of Chem. Technol. Vol 4. Pp. 145-149.

Hammed, L.A.; A.R. Adedeji; E.U. Asogwa and O.S.Ibiremo (2007). Constraints to cashew production in Nigeria. Paper presented at the cashew stakeholders meeting organized by the African Cashew alliance (ACA) held at IITA, Ibadan (January 26, 2007). $12 \mathrm{pp}$.

Igboekwe, A.D. (1982) Observation on Analeptes trifasciata F. (Coleoptera:Cerambycidae). CRIN Ann. Rep. Pp. 20-21.

Igboekwe, A.D. (1983) Ecology of cashew sterm gridler $A$. trifasciata in Nigeria. CRIN Ann. Rep. P 28.

Igboekwe, A.D. (1984) Distribution of the cashew stem gridler, A. trifasciata in Nigeria. CRIN Ann. Rep. Pp. 49-52.

Igboekwe, A.D. (1985) Injury to young plant by the redbanded thrips, Selenothrips rubrocinctus Giard(Thysanoptera:Thripidae) Agric Ecosyst Env. 13(1): 25-30.

Kubo, I.; S. Komatsu and M. Ochi (1986). Molluscicides from cashew, Anacardium occidentale and their large scale isolation. J. Agric Food Chem. 41: 1012-1015.

Lepage, E.S. and A.T. Delelis (1980). Protecting wood against dry wood termite with cashew nut shell oil. Forest Prod. J. 36(6): 35- 36.

Lubi, M.C. and E.T. Thachil (2000). Cashew nut shell liquid (CNSL) - A versatile monomer for polymer synthesis. Brill Academic Publishers. 1385 - 772X: 123-153.

Murthy, B.G.K. and M.A. Sivasamban (1985). Recent trends in CNSL utilization. Cashew Research and development:Proceedings of the International Cashew Symposium, Cochin, Kerala, India. March 12-15, 1979. Pp. 201-207.
Nandi, B.K. (1998). Cashew nut nutritional aspects. In: Integrated Production Practices of Cashew in Asia. Edited by Papademetriou, M.K. and E.M. Herath. FAO/UN. File://A:IFAO Document Repositoryfiles|AC45/EOB.HT M. 8p.

Ohler, J.G. (1966). Review Article, Cashew Nut processing. Tropical Abstracts. 21(9):1792-2007.

Ohler, J.G. (1967) Cashew growing. Tropical Abstracts (The Netherlands). 22(1): 1-9.

Ohler, J.G. (1979) Cashew. Koninklijk Instituut Voor deTropen Amsterdam.260pp

Ojeh, O. (1985). Cashew kernel, another locally available source of vegetable oil. Nigeria Agric. Journal. 19/20: 50-56.

Ojeh, O.A. and D.O. Falowo (1983). Organoleptic assessment of chocolate made partly from cashew kernel meal. Cashew. Causerie 1: 17-19.

Olunloyo, A.O. (1989) Insects as a source of inoculum in fungal infection of cashew flowers. Ann. Rep. CRIN. P. 53.

Olunloyo, A.O. and A.D. Igboekwe (1985) Biology and control of pests and diseases of Cashew, Anacardium occidentale. An invited symposium paper to mark the $21^{\text {st }}$ Anniversary of establishment of CRIN.

Omole, M.M. (1977) The phenology of the insect pests associated with cashew in Nigeria. CRIN Ann. Rep. P. 96

Togun, A. (1977) A review of the prospect of Cashew Industry. $39 \mathrm{pp}$.

Topper, C.P. (2002) Issues and constraints related to the development of cashew nuts from five selected African countries (Cote d" Ivoire, Ghana, Guniea, Guniea Bissau \& Nigeria). Project No. INT/W3/69. 24pp.

Topper, C.P.; P.D.S. Caligari; M. Camara; S. Diaora ; A. Djaha; F. Coulibay; A.K. Asante;A. Boamah; E.A. Ayodele and P.O. Adebola (2001). West African Regional Cashew Survey Report (Guinea, Guinea Bissau, Cote D'Ivore, Ghana and Nigeria). Sustainable Tree Crop Programme (STCP) and Biohybrids Agrisystem Ltd. U.K. 1: 110pp.

Weerasena, O.V.D.S.J.; A.S. Amarasekara and R.L.C. Wijesundera (1993). Fungicidal activity of synthetically modified cashew nut shell. J. Nat Sc. Coun. Sri-Lanka. 21: $253-258$ 